\title{
STIGMATIZATION OF PSYCHIATRIC PATIENTS AMONG STUDENTS IN SERBIA
}

\author{
Gordana Nikolić1 ${ }^{1}$ Maja Stanojković2 , Miroslav Krstić3 , Olivera Žikić1 ${ }^{1}$ Nikola Stojanović4,

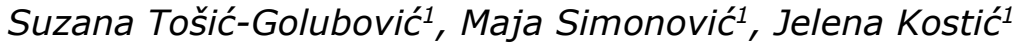

\begin{abstract}
Social psychiatry emphasizes the inclusion of mentally ill persons in family and social life. The negative attitude towards them is still an obstacle for achieving the best treatment results and their optimal quality of life. Young educated people could be an important community factor in the fight against stigmatization of psychiatric patients. The aim of the study was to determine the difference in attitudes among Serbian students attending different faculties, as well as to find out the correlation between students' attitudes and their demographic characteristics. The study involved 408 Serbian university students. The respondents were divided into three groups to determine the differences in attitudes between groups with different educational levels. We have used the Attitude Questionnaire and Demographic Questionnaire for this purpose. Medical students who had passed their exam in psychiatry, those who experienced psychological and psychiatric problems themselves, and those with a mentally ill family member had a positive attitude towards the mentally ill. Future health workers and the family members of mentally ill individuals are most important in the attempts to decrease stigmatization of psychiatric patients.
\end{abstract}

Acta Medica Medianae 2020;59(2):93-99.

Key words: stigmatization, students, psychiatric patients

\footnotetext{
${ }^{1}$ University of Niš, Faculty of Medicine, Department of Psychiatry, Niš, Serbia

'University of Niš, Faculty of Medicine, Student of Medicine, Niš, Serbia

${ }^{3}$ University of Priština, Faculty of Philosophy, Kosovska

Mitrovica, Serbia

${ }^{4}$ University of Niš, School of Medicine, Department for Physiology, Niš, Serbia
}

Contact: Gordana Nikolić

Vizantijski Bulevar 114/11, 18000 Niš, Serbia

E-mail: gordanani@gmail.com

\section{Introduction}

In the contemporary complex human society, one in four people will experience some mental health issue throughout his life. Psychiatric illnesses have always been present, in primitive, as well as in highly civilized communities all over the world. In old times, the mentally ill were considered possessed by either divine or evil forces. These were the first attempts at understanding human psychology, its alterations, as well as the stigmatization of mentally ill (1).
In more recent past, psychoanalytic and biologically oriented scientists made a great contribution to understanding and treating mental illnesses. While the knowledge has accumulated, the attitudes towards psychiatric patients have also improved. Nevertheless, the society tends to mark these persons as incurable and even health professionals stigmatize them as undesirable (2). Stigma in psychiatry is defined as "a set of negative attitudes and beliefs that motivate public opinion to fear, avoid, refute and discriminate against people suffering from mental illness" (3). Some studies have confirmed the presence of more pessimistic views on the outcome of mental illnesses by mental health professionals than by general population (4). In the research by Corrigan, stigmatization in mental health institutions contributed to low self-esteem, frustration, isolation and worse outcome of psychiatric patients, especially in the domains of housing, employment, education $(5,6)$. There is a negative correlation between the experience of stigma and successful recovery in mental disorders. Many of these patients give up their treatments when exposed to stigmatization (7). Even some physicians do not diagnose or treat psychiatric patients, wrongly assessing their complaints as hallucinations or hypochondriacal preoccupations.

Considering these problems, we wanted to investigate the presence of stigma towards psychiatric patients in the student population in Niš. 
Further, we wanted to find out if there are any differences in attitudes towards mental illnesses between students of medicine and students from the Faculty of Philosophy, their demographic characteristics, and educational or personal experiences with psychiatric diseases.

\section{Methods and subjects}

Our investigation involved 408 subjects, 290 females and 118 males, all students from Niš. They were divided into three groups of 136 respondents. The first group (group A) consisted of students of medicine who passed their examination in psychiatry ( $V$ and VI study year). The second group (group B) consisted of medical students who had not attended the classes in clinical psychiatry (I, II, III, IV study years). The third group (group $C$ ) consisted of students from the Faculty of Philosophy, Departments of Psychology, Pedagogy and Social Science. All participants gave their written consent for the study and the study was approved by the Ethics Committees of these Faculties. The survey was conducted in late 2018 and early 2019.

A sociodemographic questionnaire was used to collect the respondents data: gender, type of faculty they attended, study year, whether they were living with or without their families, their previous experience of psychological issues or psychiatric diagnoses, whether they ever seeked pschological/psychiatric help up to that time, presence of psychiatric patients in their own families, and presence of mental health professionals in their families.
In order to evaluate the attitude towards persons with mental disorders, the Attitude questionnaire containing 18 items related to the attitude towards psychiatric patients was used. The questionnaire was previously constructed and validated in a research performed at the Faculty of Philosophy in Niš. All the answers were rated on the Likert scale from 1 to 5 as follows:

$$
\begin{aligned}
& 1 \text { = completely incorrect; } \\
& 2 \text { = mostly incorrect; } \\
& 3=\text { I am not sure; } \\
& 4=\text { mostly true; } \\
& 5=\text { completely true. }
\end{aligned}
$$

The higher obtained score meant a more negative attitude, except for the items $1,6,7,17,18$, which were coded reversely, for the purpose of statistical analysis. The Attitude questionnaire score ranged from 18 to 90 , and the scale reliability was estimated by Cronbach's alpha $=0.75$.

\section{Results}

In our sample of 408 subjects, $71 \%$ were females. Demographic data indicated that $80 \%$ of students lived with their families, and that over a half of them had never had any psychological problems. Of those who experienced some mental issues, less than $20 \%$ had sought professional help. About one-third of the respondents had a relative

\begin{tabular}{|c|c|c|c|c|c|c|c|c|}
\hline \multirow[t]{2}{*}{ ITEMS } & \multicolumn{2}{|c|}{$\begin{array}{c}\text { GROUP A } \\
\text { N }(\%)\end{array}$} & \multicolumn{2}{|c|}{$\begin{array}{c}\text { GROUP B } \\
\text { N (\%) }\end{array}$} & \multicolumn{2}{|c|}{$\begin{array}{c}\text { GROUP C } \\
\text { N (\%) }\end{array}$} & \multicolumn{2}{|c|}{$\begin{array}{l}\text { TOTAL } \\
\text { N }(\%)\end{array}$} \\
\hline & YES & NO & YES & NO & YES & NO & YES & No \\
\hline Living alone & $\begin{array}{c}30 \\
(22.05) \\
\end{array}$ & $\begin{array}{c}106 \\
(77.94) \\
\end{array}$ & $\begin{array}{c}28 \\
(20.58) \\
\end{array}$ & $\begin{array}{c}108 \\
(79.41) \\
\end{array}$ & $\begin{array}{c}23 \\
(16.91) \\
\end{array}$ & $\begin{array}{c}113 \\
(83.08) \\
\end{array}$ & $\begin{array}{c}81 \\
(19.85) \\
\end{array}$ & $\begin{array}{c}327 \\
(80.14) \\
\end{array}$ \\
\hline Psychologi issues* & $\begin{array}{c}74 \\
(54.41)\end{array}$ & $\begin{array}{c}62 \\
(45.58) \\
\end{array}$ & $\begin{array}{c}53 \\
(38.97)\end{array}$ & $\begin{array}{c}83 \\
(61.02)\end{array}$ & $\begin{array}{c}70 \\
(51.47)\end{array}$ & $\begin{array}{c}66 \\
(48.52) \\
\end{array}$ & $\begin{array}{c}197 \\
(48.28) \\
\end{array}$ & $\begin{array}{c}211 \\
(51.57)\end{array}$ \\
\hline Seeking help* & $\begin{array}{c}29 \\
(21.32) \\
\end{array}$ & $\begin{array}{c}107 \\
(78.67) \\
\end{array}$ & $\begin{array}{c}21 \\
(15.44) \\
\end{array}$ & $\begin{array}{c}115 \\
(84.55) \\
\end{array}$ & $\begin{array}{c}27 \\
(19.85) \\
\end{array}$ & $\begin{array}{c}109 \\
(80.14) \\
\end{array}$ & $\begin{array}{c}77 \\
(18.12) \\
\end{array}$ & $\begin{array}{c}331 \\
(81.12) \\
\end{array}$ \\
\hline $\begin{array}{l}\text { Psychological } \\
\text { issues of family } \\
\text { member* }\end{array}$ & $\begin{array}{c}42 \\
(30.88)\end{array}$ & $\begin{array}{c}94 \\
(69.11)\end{array}$ & $\begin{array}{c}42 \\
(30.88)\end{array}$ & $\begin{array}{c}94 \\
(99.11)\end{array}$ & $\begin{array}{c}45 \\
(33.08)\end{array}$ & $\begin{array}{c}91 \\
(66.91)\end{array}$ & $\begin{array}{c}129 \\
(31.61)\end{array}$ & $\begin{array}{c}279 \\
(68.38)\end{array}$ \\
\hline $\begin{array}{l}\text { Mental health } \\
\text { worker as family } \\
\text { member }\end{array}$ & $\begin{array}{c}8 \\
(5.88)\end{array}$ & $\begin{array}{c}128 \\
(94.11)\end{array}$ & $\begin{array}{c}12 \\
(8.82)\end{array}$ & $\begin{array}{c}124 \\
(91.17)\end{array}$ & $\begin{array}{c}7 \\
(5.14)\end{array}$ & $\begin{array}{c}129 \\
(94.85)\end{array}$ & $\begin{array}{c}27 \\
(6.61)\end{array}$ & $\begin{array}{c}381 \\
(93.38)\end{array}$ \\
\hline Gender & $\begin{array}{c}\text { Female } \\
101 \\
(74.26) \\
\end{array}$ & $\begin{array}{c}\text { Male } \\
35 \\
(25.73) \\
\end{array}$ & $\begin{array}{c}\text { Female } \\
98 \\
(72.05) \\
\end{array}$ & $\begin{array}{c}\text { Male } \\
38 \\
(27.94) \\
\end{array}$ & $\begin{array}{c}\text { Female } \\
91 \\
(66.91) \\
\end{array}$ & $\begin{array}{c}\text { Male } \\
45 \\
(33.08) \\
\end{array}$ & $\begin{array}{c}\text { Female } \\
290 \\
(71.07) \\
\end{array}$ & $\begin{array}{c}\text { Male } \\
118 \\
(28.92) \\
\end{array}$ \\
\hline
\end{tabular}
who sought psychiatric help, and only $7 \%$ of the respondents had a family member involved in the profession related to mental health care (Table 1 ).

Table 1. Demographic data of the sample

Group A - Students of medicine who passed exam in psychiatry;

Group B - Students of medicine who have not attended classes of clinical psychiatry;

Group C - Students from Faculty of Philosophy;

*Demographic data with statistical significance relation to positive attitude towards psychiatric patients. 
Comparing the attitude scores of the Attitude questionnaire between the groups, we found that there was a statistically significant difference in the overall attitude towards mentally ill persons ( $p<$ 0.001) (Table 2).

The level of statistical significance was reached in nine items related to the knowledge about mental illnesses, socializing with the affected people and having a psychiatric patient in one's own family. The analysis indicated less stigmatization in a group of medical students who had passed the psychiatry exam compared to other two groups (0.001). A more positive attitude was present in group $A$, while there were no differences between group $B$ and group C (40.85 \pm 6.978; $44.85 \pm$ $7.335 ; 44.52 \pm 7.522)$.

Table 2. Difference in attitude between the studied groups

\begin{tabular}{|c|c|c|c|c|}
\hline ITEMS & GROUP A & $\begin{array}{l}\text { M } \pm \text { SD } \\
\text { GROUP B }\end{array}$ & GROUP C & $\mathbf{p}$ \\
\hline $\begin{array}{l}\text { 1. I would hang out with a person with } \\
\text { diagnosed mental illness.* }\end{array}$ & $2.24 \pm 1.036$ & $2.35 \pm 0.923$ & $2.53 \pm 0.910$ & 0.046 \\
\hline $\begin{array}{l}\text { 2. I'm afraid to communicate with a } \\
\text { mentally ill person } *\end{array}$ & $1.80 \pm 0.995$ & $2.18 \pm 1.032$ & $2.38 \pm 1.040$ & $<0.001$ \\
\hline 3. Mentally ill persons are dangerous.* & $2.39 \pm 0.800$ & $2.67 \pm 0.911$ & $2.56 \pm 0.876$ & 0.028 \\
\hline $\begin{array}{l}\text { 4. Psychiatric patients are noticeable and } \\
\text { recognizable in the society. }\end{array}$ & $2.71 \pm 1.135$ & $2.71 \pm 1.025$ & $2.85 \pm 1.003$ & 0.491 \\
\hline $\begin{array}{l}\text { 5. People are generally afraid of mental } \\
\text { patients. }\end{array}$ & $4.20 \pm 0.581$ & $4.10 \pm 0.676$ & $4.08 \pm 0.058$ & 0.243 \\
\hline $\begin{array}{l}\text { 6. The media should not spread prejudice } \\
\text { and a negative attitude towards mental } \\
\text { illness.* }\end{array}$ & $1.35 \pm 0.715$ & $3.74 \pm 1.699$ & $1.46 \pm 0.729$ & $<0.001$ \\
\hline $\begin{array}{l}\text { 7. I would not mind that my partner is a } \\
\text { mentally ill. }\end{array}$ & $3.63 \pm 1.141$ & $3.81 \pm 1.099$ & $3.70 \pm 1.104$ & 0.420 \\
\hline $\begin{array}{l}\text { 8. I do not even like to talk about mental } \\
\text { illness.* }\end{array}$ & $1.51 \pm 0.861$ & $1.79 \pm 1.105$ & $2.19 \pm 1.183$ & $<0.001$ \\
\hline $\begin{array}{l}\text { 9. I do not want to know anything about } \\
\text { mental illness.* }\end{array}$ & $1.09 \pm 0.354$ & $1.10 \pm 0.295$ & $1.30 \pm 0.648$ & $<0.001$ \\
\hline 10. I know nothing about mental illness.* & $1.17 \pm 0.480$ & $1.61 \pm 0.845$ & $1.99 \pm 0.977$ & $<0.001$ \\
\hline $\begin{array}{l}\text { 11. I recognize a lot of people who are } \\
\text { mentally ill. }\end{array}$ & $2.75 \pm 1.031$ & $2.74 \pm 1.116$ & $2.59 \pm 1.007$ & 0.360 \\
\hline $\begin{array}{l}\text { 12. The people have every right to rejects } \\
\text { the mentally ill. }\end{array}$ & $1.63 \pm 0.860$ & $1.84 \pm 0.968$ & $1.82 \pm 0.888$ & 0.104 \\
\hline $\begin{array}{l}\text { 13. The one who suffers from mental illness } \\
\text { cannot adapt to the life of healthy people. }\end{array}$ & $2.36 \pm 0.866$ & $2.42 \pm 0.993$ & $2.41 \pm 1.036$ & 0.862 \\
\hline $\begin{array}{l}\text { 14. I'm afraid I could go crazy. } \\
\text { 15. The behavior of a mentally ill differs }\end{array}$ & $1.93 \pm 1.059$ & $2.13 \pm 1.256$ & $2.03 \pm 1.205$ & 0.380 \\
\hline $\begin{array}{l}\text { significantly from the behavior of healthy } \\
\text { people. }\end{array}$ & $3.01 \pm 0.915$ & $3.00 \pm 1.033$ & $3.06 \pm 0.964$ & 0.863 \\
\hline $\begin{array}{l}\text { 16. I Would be ashamed of my family } \\
\text { member's mental illness.* }\end{array}$ & $2.01 \pm 1.075$ & $1.75 \pm 0.925$ & $2.04 \pm 1.108$ & 0.038 \\
\hline $\begin{array}{l}\text { 17. It is difficult to distinguish a healthy and } \\
\text { mentally ill person. }\end{array}$ & $3.30 \pm 0.969$ & $3.35 \pm 1.002$ & $3.19 \pm 1.022$ & 0.660 \\
\hline $\begin{array}{l}\text { 18. I try to find out more about the nature of } \\
\text { mental illness.* }\end{array}$ & $1.71 \pm 0.818$ & $1.95 \pm 0.976$ & $2.35 \pm 1.131$ & $<0.001$ \\
\hline TOTAL SCORE & $40.85 \pm 6.978$ & $44.85 \pm 7.335$ & $44.52 \pm 7.522$ & $<0.001$ \\
\hline
\end{tabular}

Group A - Students of medicine who passed the exam in psychiatry;

Group B - Students of medicine who have not attended classes of clinical psychiatry;

Group C - Students from other faculties;

AVR - Arithmetic mean;

SD - Standard deviation;

p- ANOVA level of statistical significance;

$*$ Items which significantly differ between groups. 
Linear correlation of the sample established a correlation between some demographic characteristics and attitude towards psychiatric patients. A positive attitude towards the mentally ill was seen in students who had experienced some psychological issues themselves $(p<0.002)$, those who asked for professional help ( $p<0.004)$, and those who had a mentally ill relative. A negative attitude was identified in those who denied experience of psychological/psychiatric symptoms, those who never asked for psychological support/help and did not have any family member with psychological or psychiatric issues (Table 3).

Table 3. Relation between negative attitude towards mentally ill and demographic characteristics of the sample

\begin{tabular}{|c|c|c|}
\hline $\begin{array}{l}\text { ITEMS } \\
\text { GENDER }\end{array}$ & $\begin{array}{c}\mathbf{R}^{\mathbf{2}} \\
0.052\end{array}$ & $\begin{array}{c}\mathbf{p} \\
0.294\end{array}$ \\
\hline Do you live alone? & -0.094 & 0.058 \\
\hline Have you ever had psychological/psychiatric issues?* & 0.149 & 0.002 \\
\hline Did you ever ask for psychological/psychiatric help?* & 0.143 & 0.004 \\
\hline Did any member of your family ever ask for psychological/psychiatric help?* & 0.193 & $<0.001$ \\
\hline Is someone in your family professional health worker? & -0.001 & 0.978 \\
\hline
\end{tabular}

\section{Discussion}

Psychiatric patients are still marginalized in the society and even the domain of medical care is not an exception. Their quality of functioning in everyday life does not depend solely on their illness, but also on social integration, which often depends on the presence of stigmatization. Despite modern treatment potentials, patients facing the stigma have limited access to many possibilities in their life. Stigmatization of psychiatric patients is present even among their family members, friends and mental health professionals. In medical settings, mentally disturbed patients are considered different and less adherent to their therapy (8).

Exploring possible stigmatization attitudes among the students of medicine, psychology, social science and pedagogy is important in early detection of the issues that could possibly influence future professionals in the field of mental health. This is essential for determining possible targets for antistigma interventions, since the opinions and behaviors of young people are highly modifiable (9). The students in our sample with basic knowledge of psychiatry had a more positive view on the mentally ill than other respondents. They were all young, healthy people, but those who experienced some psychological issues usually did not seek professional help. This could be an indicator of stigma and shame. The literature data suggests the importance of early interventions in psychological crisis, in order to overcome emotional distress (7). Avoidance of dealing with issues with the help of professionals, could lead to unhealthy behavior or psychopathological reactions of young people affecting their mental health. Risk health behaviors are often the way of relieving stress and could be an introduction to more serious medical conditions.

96
Less stigma towards the people with psychiatric issues was present in those students who had a family member with diagnosis of a mental disorder and who had not a mental health professional in the family. Such a positive attitude could be explained by their being better informed about the capability of mentally ill persons to recover and integrate into society. The available literature also suggests that personal relatedness to a mentally disturbed person is the way to understand, support and accept all such people as equal members of society (9).

Our assumption that education was important in building the right attitude towards the mentally ill, with or without any personal experience with psychological issues, was confirmed. The results indicated that medical students who had passed their exam in clinical psychiatry had a more positive attitude, while other medical students as well as students from other faculties had a more negative attitude towards psychiatric patients. This is in line with the findings of Zaninotto et al. from 2018, where male students of psychology in higher study years have had a more positive attitude and opinion about mentally ill patients (10). The investigators support the idea of "open doors" in psychiatric wards which would hopefully reduce social isolation of these patients. In their study, no other demographic variables were in correlation to attitude, but some personality traits, such as Agreeableness and Openness were positively associated with empathy towards psychiatric patients. We did not investigate personality types in our sample. However, our experience in clinical practice and team work also confirms the assumption that certain personality traits are more favorable in that regard for mental health workers. Future medical workers should be sensitive to persons with psychological issues and capable of accepting them as any other patients and treat them 
with equal care as those without emotional disturbance. We could well expect that medical professionals had more profound knowledge of psychiatry and a more positive attitude towards mental illnesses. Nevertheless, some studies have demonstrated negative opinions and behaviors towards psychiatric patients in doctors, nurses, and psychologists, not different from that in the general population (11). Such an observation emphasizes the importance of education and practical experience in dealing with psychiatric patients, which could improve their being accepted as clients.

In our subjects, a positive attitude was encountered in those who had knowledge about psychiatry and some kind of first-hand experience with psychological/psychiatric issues, (whether personally experienced or seen in a family member). The result is similar to the findings of Yamaguchi et al., who have reported that the most important and effective way for reducing mental health related stigma are social contacts with the mentally ill. The contacts could be indirect or direct, as through professional training in psychiatric units (12).

Videotaped cases of some psychological issues or psychiatric syndromes could be an acceptable way to introduce college students to mental illnesses. This first step may decrease social distance and help future mental health workers to understand and build up a favorable opinion about psychiatric disorders. Direct contacts of students with patients, supervised by ward psychiatrists and psychologists, are the best way to get a realistic picture about patients' way of thinking, emotional expression and behavior.

Our results indicated that some factors were correlated to better attitudes towards people with mental health problems.
The limitation of the study was a limited representativeness of the sample, which involved students of medicine and social science, who had already chosen to be educated in the profession oriented towards helping people. Therefore, the results cannot be generalized to involve the general population as well. We did not explore other parameters, such as personality characteristics, which could also play a role in the formation of attitudes towards psychiatric patients. In studying the greatest obstacles to the inclusion of psychiatric patients into society, future work in this field should include other people of different ages and education levels.

\section{Conclusion}

In the studied student population in Serbia, formal education and personal experience of psychological issues are associated with a more positive attitude towards mental illnesses. Social interaction with ill persons could decrease stigma, especially if mental problems are encountered in one's family on a day-to-day basis. Educational programs should point out the problem of stigmatization, helping future professionals in field of medicine and social sciences to deal with all the patients without any prejudice.

\section{Acknowledgments}

The research is a part of the scientific project number 47023 "Kosovo and Metohija between National Identity and Euro-Integration" financed by the Ministry of Education, Science and Technological Development of the Republic of Serbia. 


\section{References}

1. Sadock BJ, Sadock VA. Ruis P. Kaplan \& Sadock's Synopsis of Psychiatry. Behavioral Sciences/Clinical Psychiatry. $11^{\text {th }}$ ed. Philadelphia (PA): Wolters Kluwer; 2016. [PubMed]

2. Allan Tasman, Jerald Kay, Jefferey A. Liberman, Michael B. First, Mario Maj. Psychiatry. $3^{\text {rd }}$ ed. Hoboken (NJ): John Wiley \& Sons; 2008. [CrossRef]

3. Centers for Disease Control and Prevention, Substance Abuse and Mental Health Services Administration, National Association of County Behavioral Health and Developmental Disability Directors, National Institute of Mental Health, The Carter Center Mental Health Program. Attitudes Toward Mental Illness: Results from the Behavioral Risk Factor Surveillance System. 2012.

4. Nordt C,Rossler W, Lauber C. Attitudes of mental health professionals toward people with shizophrenia and major depression. Shioph Bull 2006;32:709-14. [CrossRef] [PubMed]

5. Corrigan $\mathrm{P}$, Larison $\mathrm{L}$, Rush $\mathrm{N}$. Self -stigma and "the why try" effect: Impact on life goals and evidencebased practices. World Psychiatry 2009;8:75-8.

[CrossRef] [PubMed]

6. Corrigan PW, River LP, Lundin RK, Penn LD, UphoffWasowski K, Campion J, et al. Three strategies for changing attributions about severe mentall illness. Schizophrenia Bulletin. 2001;27:187-95. [CrossRef] [PubMed]
7. Ociskova M, Prasko J, Kamaradova D, Grambal A, Latalova K, Sigmundova Z. Relationship between internalized stigma and treatment efficacy in mixed neurotic spectrum and depressive disorders. Neuroendocrinology Letters 2014;35(8):101-7. [PubMed]

8. Kecmanović D. (Ne)mogućnost prevencije stigma duševnog poremećaja i destigmatizacije osoba sa duševnim poremećajem. Psihološka istraživanja 2010; 13(2):185-217. [CrossRef]

9. Popescu CA, Buzoianu AD, Suciu SM, Armean SM. Attitudes toward mentally ill patients: a comparison between Romanian and international medical students. Clujul Med 2017;90(4):401-6. [CrossRef] [PubMed]

10. Zaninotto L, Qian J, Sun Y, Bassi G, Solmi M, Salcuni S. Gender, personality traits and experience with psychiatric patients as predictors of stigma in italian psychology students. 2018;Front Public Health 6:362. [CrossRef] [PubMed]

11. Overton SL, Medina SL. The Stigma of Mental Illness. Journal of Counseling and Development 2008; 86: 143-51. [CrossRef]

12. Yamaguchi S, Wu Si, Biswas M, Yate M, Aoki Y, Barley $E A$, et al. Effects of short- term interventions to reduce mental health- related stigma in university or college students: a systematic review. J Nerv Ment Dis 2013; 201:490-503. [CrossRef] [PubMed] 


\title{
STIGMATIZACIJA PSIHIJATRIJSKIH BOLESNIKA OD STRANE STUDENATA U SRBIJI
}

\author{
Gordana Nikolić1, Maja Stanojković ${ }^{2}$, Miroslav Krstić3, Olivera Žikić1, Nikola Stojanović4, \\ Suzana Tošić-Golubović ${ }^{1}$, Maja Simonović ${ }^{1}$, Jelena Kostić ${ }^{1}$
}

\begin{abstract}
${ }^{1}$ Univerzitet u Nišu, Medicinski fakultet, Katedra za psihijatriju, Niš, Srbija
¿Univerzitet u Nišu, Medicinski fakultet, student medicine, Niš, Srbija

${ }^{3}$ Univerzitet u Prištini, Filozofski fakultet, Kosovska Mitrovica, Srbija

${ }^{4}$ Univerzitet u Nišu, Medicinski fakultet, Katedra za fiziologiju, Niš, Srbija
\end{abstract}

Kontakt: Gordana Nikolić

Vizantijski bulevar 114/11, 18000 Niš, Srbija

E-mail: gordanani@gmail.com

Socijalna psihijatrija ističe značaj uključivanja mentalno obolelih osoba u porodični i socijalni život. Negativan stav prema ovim osobama predstavlja i dalje prepreku za postizanje najboljeg mogućeg tretmana i poboljšanja kvaliteta života. Mladi, edukovani ljudi mogli bi biti značajni činilac zajednice u borbi protiv stigmatizacije psihijatrijskih bolesnika. Cilj studije bio je da odredi razlike u stavovima srpskih studenata, koji pohađaju različite fakultete, kao i da otkrije povezanost njihovih stavova sa demografskim karakteristikama. Istraživanje je obuhvatilo 408 studenata srpskih univerziteta. Ispitanici su bili podeljeni u tri grupe, radi utvrđivanja razlike u stavovima između studenata različitih edukacijskih grupa. Koristili smo upitnik o stavovima i upitnik o demografskim karakteristikama. Studenti medicine, koji su položili ispit iz psihijatrije i oni koji su i sami iskusili psihološke i psihijatrijske probleme i oni koji su imali mentalno obolele članove porodice, imali su pozitivan stav prema mentalno obolelim osobama. Budući zdravstveni radnici i članovi porodice mentalno obolelih značajni su za smanjivanje stigmatizacije psihijatrijskih bolesnika.

Acta Medica Medianae 2020;59(2):93-99.

Ključne reči: stigmatizacija, studenti, psihijatrijski bolesnici 